\title{
Correction to: Versatile biotechnological applications of amylosucrase, a novel glucosyltransferase
}

\author{
Dong-Ho Seo ${ }^{1}$ - Sang-Ho Yoo $^{2}$ - Seung-Jun Choi ${ }^{3}$ Y Young-Rok Kim ${ }^{4}$. \\ Cheon-Seok Park ${ }^{4}(\mathbb{D}$
}

(C) The Author(s) 2020

\section{Correction to: Food Sci Biotechnol (2020) 29(1):1-16 https://doi.org/10.1007/s10068-019-00686-6}

The article "Versatile biotechnological applications of amylosucrase, a novel glucosyltransferase", written by Dong-Ho Seo, Sang-Ho Yoo, Seung-Jun Choi, Young-Rok Kim and Cheon-Seok Park, was originally published Online First without Open Access. After publication in volume 29 , issue 1 , page 1-16 the author decided to opt for Open Choice and to make the article an Open Access

The original article can be found online at https://doi.org/10.1007/s10068-019-00686-6.

\footnotetext{
Cheon-Seok Park

cspark@khu.ac.kr

Dong-Ho Seo

dhseo@jbnu.ac.kr

Sang-Ho Yoo

shyoo@sejong.ac.kr

Seung-Jun Choi

choisj@seoultech.ac.kr

Young-Rok Kim

youngkim@khu.ac.kr
}

1 Department of Food Science and Technology, College of Agriculture and Life Sciences, Jeonbuk National University, Jeonju 54896, Republic of Korea

2 Department of Food Science and Biotechnology, and Carbohydrate Bioproduct Research Center, Sejong University, Seoul 05006, Republic of Korea

3 Department of Food Science and Technology, Seoul National University of Science and Technology, Seoul 01811, Republic of Korea

4 Graduate School of Biotechnology and Institute of Life Science and Resources, Kyung Hee University, Yongin 17104, Republic of Korea publication. Therefore, the copyright of the article has been changed to (C) The Author(s) 2020 and the article is forthwith distributed under the terms of the Creative Commons Attribution 4.0 International License (http://creative commons.org/licenses/by/4.0/), which permits use, duplication, adaptation, distribution and reproduction in any medium or format, as long as you give appropriate credit to the original author(s) and the source, provide a link to the Creative Commons license, and indicate if changes were made.

The original article has been corrected.

Open Access This article is licensed under a Creative Commons Attribution 4.0 International License, which permits use, sharing, adaptation, distribution and reproduction in any medium or format, as long as you give appropriate credit to the original author(s) and the source, provide a link to the Creative Commons licence, and indicate if changes were made. The images or other third party material in this article are included in the article's Creative Commons licence, unless indicated otherwise in a credit line to the material. If material is not included in the article's Creative Commons licence and your intended use is not permitted by statutory regulation or exceeds the permitted use, you will need to obtain permission directly from the copyright holder. To view a copy of this licence, visit http://creativecommons. org/licenses/by/4.0/.

Publisher's Note Springer Nature remains neutral with regard to jurisdictional claims in published maps and institutional affiliations. 